\title{
A constituição do silêncio em bibliotecas comunitárias*
}

\author{
Gustavo Grandini Bastos**
}

\begin{abstract}
Resumo: O interesse desse texto é discutir o silêncio dentro da perspectiva da Análise do Discurso de formulação pecheuxtiana e observar o seu funcionamento na constituição das bibliotecas comunitárias, usadas como corpus dessa pesquisa. O objetivo é marcar um distanciamento da visão de espaço de ausência que muito ainda circula como representativo acerca do silêncio, instaurando uma perspectiva outra que o observa como múltiplo e repleto de sentidos.
\end{abstract}

Palavras-Chave: silêncio; bibliotecas comunitárias; sentidos.

O silêncio é o luxo das palavras, sendo necessário ouvi-lo. A palavra dita, inevitavelmente, oculta outras tantas que deixaram de ser proferidas. Essa reflexão da escritora Clarice Lispector (1998) dialoga ricamente com o conceito de silêncio abordado nessa discussão, que é aquele pensado nas teias teóricas da Análise do Discurso de formulação pecheuxtiana.

A comunicação e a linguagem são atravessadas pela incompletude (PÊCHEUX; GADET, 2011), não raro, observa-se a circulação da noção de silêncio como aquele que é absolutamente ausente de significados e que apenas compreende a falta do dizer, o que corrobora para seu entendimento como sinônimo de vazio. Com os estudos de Eni Orlandi (1997) estabelece-se uma importante (e outra) forma de pensar o silêncio: não mais uno, no singular, mas sim, plural; dessa forma, temos os silêncios, visto que se "as palavras são múltiplas [...] os silêncios também o são" (Ibid., p. 29) e também são carregados de significados e sentidos. Dessa maneira, não cabe uma observação do silêncio como sinônimo de vazio, mas sim, como um espaço de horizonte na linguagem (Ibid.).

De acordo com Orlandi (1997), temos o silêncio fundador ou fundante e a política do silêncio. Compreendido como aquele que atravessa as palavras, o silêncio fundador existe entre elas e indica que o sentido pode sempre ser outro, isso tudo justifica a titulação de espaço fundador da linguagem (Ibid.). A política do silêncio diz respeito ao entendimento de que o sujeito apaga sentidos outros ao enunciar, sendo esse um preço inevitável do processo discursivo. Esse conceito é desmembrado em duas pequenas especificações: i) o silêncio constitutivo que "preside qualquer produção de linguagem" (Ibid., p. 75); e o ii) silêncio local, compreendido como o procedimento de interdição do dizer do sujeito, no caso a censura, no qual ocorre a proibição da circulação de determinados sentidos (Ibid.).

Historicamente, observa-se o silêncio apresentado como algo constitutivo das bibliotecas, tendo sua existência marcando-as como ponto identificatório da Antiguidade até os dias atuais, nos quais o silêncio é observado dentro de uma

\footnotetext{
*Esse texto é um recorte do TCC "Bibliotecas Comunitárias em Discurso" (2010).

* Mestrando em Ciência, Tecnologia e Sociedade do Centro de Educação e Ciências Humanas da UFSCar. Bolsista CAPES. Pesquisador do E-L@DIS - Laboratório Discursivo: sujeito, rede eletrônica e sentidos em movimento, da FFCLRP/USP. E-mail: gugrandini@uol.com.br
}

fragmentum, N. 32. Laboratório Corpus: UFSM, Jan./ Mar. 2012 
perspectiva ilusória de vazio da linguagem, sendo exigido através das inúmeras plaquetas de silêncio que abarrotam as paredes de muitas instituições. Essas plaquetas correspondem às marcas do silêncio local.

As bibliotecas comunitárias são instituições existentes em vários países do mundo e são divididas na literatura da Ciência da Informação em duas categorias: i) as construídas em nações desenvolvidas, que são instituições públicas que realizam suas ações em espaços de exclusão e focam seu trabalho no atendimento dessas comunidades, atuando, por exemplo, com desempregados e imigrantes; e ii) as bibliotecas dos países em desenvolvimento que são aquelas que se constituem em espaços marginalizados por conta da ausência de centros de informação e leitura no atendimento dessas comunidades que apresentam pouca (ou nenhuma) assistência do Estado (MACHADO, 2008), e construídas na maioria das vezes pelos próprios membros dessas comunidades.

Para pensar a questão terminológica das bibliotecas comunitárias, elegemos o Brasil como lugar de estudo, e observamos sua importância no trabalho com sujeitos que vivem em regiões pouco atendidas pelo poder público, como assentamentos do movimento campesino, caiçaras, favelas, entre outros e na qual foi possível identificar a importância de suas ações (BASTOS; ROMÃO, 2011). Essas instituições são constituídas em e por silêncios. Foi identificada sua pouca discussão nos espaços de divulgação científica da Ciência da Informação indicando o silenciamento acerca dessas bibliotecas em lugares importantes de reflexão da área informacional, principalmente quando comparamos com outras tipologias institucionais que ocupam com fartura esses mesmos periódicos.

Temos marcas do silenciamento de outras denominações acerca dessa instituição, como bibliotecas alternativas, bibliotecas do povo ou bibliotecas populares, que em muitos casos são usadas amplamente pelos gestores desses projetos e que apresentam todas as características de uma instituição comunitária, com exceção do não uso dessa denominação, o que acaba por silenciar essas instituições no momento de uma busca em espaços informacionais (bancos de dados, buscadores da internet, catálogos institucionais, etc.), visto que acabam silenciadas dessas contagens. Essa ação de nomear e identificar de uma forma única resulta como consequência o silenciar de outras tantas possibilidades de nomear essas bibliotecas, pois quando se diz que essas instituições são comunitárias deixa-se de apresentá-las de outras tantas formas possíveis.

É importante marcar que algumas instituições, e aqui tomaremos como exemplo as bibliotecas de presídios, não são consideradas como comunitárias em nosso contexto nacional, apesar de lidarem com grupos que são pouco atendidos pelo Estado em suas necessidades culturais e que na grande parte dos projetos analisados são formadas por iniciativa dos presidiários e composta por livros obtidos pelos detentos e suas famílias. Apesar de todos esses pontos, elas não são consideradas como bibliotecas comunitárias, são enquadradas em outras tipologias, silenciando uma série de sentidos.

Como observado, dizer resulta em silenciar. É algo que permeia nosso caminhar histórico e nossa constituição como sujeitos discursivos. Atentar para sua importância dentro da comunicação e da linguagem permite outra relação com o discurso. Observar o silêncio permeando as bibliotecas comunitárias no processo de análise construído nesse escrito possibilita a compreensão de como são afetados os 
processos de circulação discursiva que envolve esse conceito. Retomando as palavras de Lispector (1998) e Orlandi (1997), é realmente necessário observar o silêncio.

\section{Referências}

BASTOS, Gustavo Grandini; ROMÃO, Lucília Maria Sousa. A construção de bibliotecas comunitárias e o desejo de acessar: sentidos em movimento. DataGramaZero, Rio de Janeiro, v. 12, n. 4, 2011. Disponível em: <http://www.dgz.org.br/ago11/F_I_art.htm>. Acesso em: 10.jun.2011.

LISPECTOR, Clarice. Água viva. Rio de Janeiro: Rocco, 1998.

MACHADO, Elisa Campos. Bibliotecas comunitárias como prática social no Brasil. 2008. 183f. Tese (Doutorado em Ciência da Informação). Universidade de São Paulo. São Paulo: USP, 2008.

ORLANDI, Eni Puccinelli. As formas do silêncio: no movimento dos sentidos. 4. ed. Campinas, SP: Editora da Unicamp, 1997.

PÊCHEUX, Michel; GADET, Françoise. A língua inatingível. In: PÊCHEUX, Michel. Análise de discurso. Campinas, SP: Pontes, 2011. 